The International Journal of Banking and Finance, Volume 8 (Number 2) 2011: pages 19-39

\title{
EFFECTIVENESS OF CENTRAL BANK INDEPENDENCE VIA ITS INTERNAL CHARACTERISTICS
}

\author{
Carroll H. Griffin \\ Fontbonne University, United States
}

\begin{abstract}
This study examines central bank independence in developing countries of Latin America and Asia as well as selected developed countries. Many countries around the world, both developed and developing, have accepted the idea of central bank independence over the last several decades, so central banks have autonomy. A majority of studies has examined primarily the impact of central bank independence on inflation as promoting the theoretical benefits of a more stable and prosperous macroeconomic environment. However, there is only now sufficient data to empirically determine whether these claims are true. This research attempts to answer why developing economies with an informal sector resort to inflationary measures to finance their activities; how does a government induce an agent to choose the formal economy. In the trade-off between inflation and reserve requirements, the optimal policy is maximum inflation and minimum reserve requirements as increasing the steady-state utility of an optimizing agent. Also agents prefer the informal economy if policy relies on a maximum reserve requirement.
\end{abstract}

Keywords: Central Banks and Their Policies, International Financial Markets, Monetary Policy, Asia, Central bank independence, Financial markets, Inflation, Latin America

JEL Classification: G22

\section{Introduction}

This paper addresses the unintended consequences on the informal and formal sectors of an economy from the regulations on bank reserve and inflation financing observed in several developing countries. The term central bank independence (CBI) can be broadly defined as 
the degree of freedom of the central bank to pursue monetary policy without interference from political considerations (Sirivedhin and Hataiseree, 2000). In other words, independence implies that a nation's central bank can follow a trajectory outside the political realm and does not have to abide by the government's request to follow a certain monetary policy, such as printing money to pay for federal deficits (Gruben and Welch, 1993). Since being first written about in the late 1980s, many countries have come to adopt this policy and governments have come to recognize this as standard procedure. From the late 1980s to the mid-1990s, countries as diverse as Malaysia, New Zealand, Chile, Mexico, Argentina, Spain, France and Brazil granted their respective central banks more autonomy from the government (Cukierman, 1994). However, despite this proliferation, highly independent central banks in many countries of the developing world are relatively new phenomena (Boylan 2001).

The idea of granting a nation's central bank autonomy from the government, although a relatively simple one at first glance, is powerful in the sense that, if a central bank is independent in its decision making abilities, the government in power at a given time will be unable to turn back monetary decisions that have been made or, in a similar vein, force actions to be undertaken. Thus, in theory, an independent and autonomous central bank should lead to a more stable economic environment in the respective country (Maxfield, 1997). It represents a prominent transformation, because it not only removes a key aspect of economic decision making from political control but has kept many governmental powers from overturning growth-oriented central bank policies (Boylan 2001).

The primary motive behind the granting of such autonomy appears to be the belief that an independent and sovereign central bank would have more power to diminish inflation and price volatility and thusly, promote economic growth. According to Cukierman (1994), there is widespread consensus now that central banks should be independent because it helps to achieve price stability. This belief stems not only from monetary theory but also from empirical studies on the subject, both in developed and developing countries. The traditional argument for central bank autonomy is that the power to spend money (the government) should be separate from the power to print money (the central bank).

Although there has been much study done on the theoretical rationale behind it, few empirical studies, other than those examining the effects of inflation, have been conducted to 
assess accurately whether central bank independence actually leads to desirable macroeconomic outcomes. That is, although many countries have granted autonomy to their respective central bank with the hope of not only taming inflation and inflation volatility, but also achieving a broader spectrum of macroeconomic goals, such as low unemployment, sustained GDP growth, increased investment, less volatile interest rates and further financial market liberalization, many of these hopes have not been proven empirically, especially in the developing world.

The focus of this study will be to examine a select group of countries in three defined regions (Asia, Latin America, and the Developed West) and identify whether macroeconomic variables such as inflation, unemployment, interest rates, exchange rates, direct investment, exports, savings rates and economic growth have responded positively since the granting of central bank autonomy. Some of these variables have been examined indirectly in previous studies, but many of the results, in particular regarding developing countries, have been inconclusive. Thus, one of the primary contributions of this study is that it will directly examine the effects of central bank independence on these principal macroeconomic variables over a longer term period (since 1960 in most cases). We analyze both the pre- and postcentral bank independence periods. Another important contribution is that it also recognizes the heteroscedastic (variance in errors) nature of the countries' time series data, so, when necessary, utilizes a different regression model, that of Generalized Autoregressive Conditional Heteroskedasticity (i.e. GARCH). Once correlation is established, causality (which is a stronger relationship) will be examined as well.

Another of the unique contributions of this paper is that it will examine the phenomenon of financial crises as they relate to central bank independence, including the current global crisis of 2008-09. It will not only examine the effects that financial crises had on countries, but will also examine countries such as Mexico that experienced this type of crisis both before and after the central bank was made independent in order to determine what effect (if any) this independence had on the lessening of the severity of a given crisis. It is important to determine what impact, if any, central bank independence has had on lessening the severity of crises, as it is perhaps during these types of extraordinary circumstances that an independent central bank is most needed. 
The rest of the paper has four sections. Section 2 provides a brief literature review on CBI while section 3 is about the methodology to be applied in this study. The results are presented and discussed in section 4 which is followed by section 5 with concluding comments.

\section{Literature on Central Bank Independence}

\subsection{Central Bank Autonomy: An Overview}

Motivation for Autonomy: Among both developed and developing countries, there has been significant controversy regarding central bank independence. However, despite this debate, during 1990 and 1995, over 30 countries including five from Latin America granted independence to their respective central banks. This is due to most countries' central banks and finance ministries understanding and accepting that high inflation is detrimental to growth and that price stability is one of the central banks' primary functions (Maxfield, 1997). Central bank reforms have been focused in several particular areas. One is the rewriting of legal statutes regarding central bank operations and relations with other branches of the government. Another is the issue of central bank accountability, and the third is the issue of increased central bank transparency (Crowe and Meade, 2008).

Overall, one of the main factors motivating central bank reforms and the granting of autonomy by their respective country governments has been the newfound belief that central bank independence may be an institutional mechanism that leads to price stability, thus increasing the credibility of policymakers' commitments to stable prices (Diana et al., 2004). Furthermore, an independent central bank has the freedom to implement monetary and exchange rate policy in order to achieve its objective. Additionally, a clear definition and prioritization of the objectives of the central bank enhances its credibility both domestically and internationally (Gutiérrez, 2003). However, it should be noted that central bank autonomy is in many cases part of a broader package of reforms that many times includes judicial reform, privatization, removal of trade barriers, etc. (Acemoglu et al., 2008). 


\subsection{Early History and Global Events}

Although the idea of central bank independence may seem new, perhaps it is not. Independent central banks have been around since the interwar period of the earlier part of the 20-th Century, although not much was studied about them nor were the independent central banks of the time considered exceptional. Beginning in the postwar era of the early 1950s, more began to be written about them, and the idea had its supporters and detractors (Forder, 2005). However, it was only in 1988 that Alesina stated, "Independent central banks have been associated with a lower average inflation rate and may have been responsible for reducing politically induced volatility of monetary policy and inflation" and that the idea began to be accepted as common policy (Alesina, 1988). One of the early success stories was that of New Zealand, which granted its central bank autonomy in 1989 and achieved a considerable decrease in inflation rates (Carlstrom and Fuerst, 2006). By 1997, with the granting of independence to the Bank of England, the transition could be considered complete and Alesina's suggestion just ten years prior could be considered an established finding.

There are several specific reasons that the concept of central bank independence only began to take hold beginning in the late 1980s and into the 1990s. First, the highly independent central banks such as the German Bundesbank and the Swiss National Bank produced very good long-term results in achieving price stability. Their success in controlling inflation for relatively long periods of time gave initial impetus to other countries to grant autonomy to their own central banks. Second, the rampant inflation of the 1970s in many countries around the world led many political and monetary policy leaders to search for a solution to the ravaging effects of high inflation. The episodes of hyperinflation in Latin America in the 1980s (greater than 1000 per cent per year in many cases) caused these countries to look for mechanisms that would quell the recurrence of this monetary malady, and a more independent central bank was seen as a viable alternative. Third, the desire of the breakaway republics of the former Soviet Union to transform their economies into market style economies also led to further interest in the granting of autonomy to respective country central banks (Cukierman, 1994). 


\subsection{Legal vs. Operational Independence}

The conclusion of many empirical studies from the 1990s and early 2000s was that inflation is negatively related to central bank independence in both developed and developing countries. However, for central bank independence to be effective, it must not only be independent in the legal (de jure) sense, but also in the operational (de facto) sense as well. There is perhaps not a great distinction between the two in most developed countries, but in many developing countries the difference can be quite large. As long as central bank independence is only legal (formalized), and not operational in scope, the expected benefits will not occur. In fact, it may actually be counterproductive (Cukierman, 1994).

Operational independence implies that central banks are empowered, among other things, to control their own interest rates, and thus, those of commercial banks in the respective country. The differences between de jure and de facto independence is great in countries where institutions and rule of law is weak (Carstens and Jácome 2005). Therefore, one explanation for the weak empirical relationship between central bank independence and inflation is that the legal measure of independence fails to capture operational independence, particularly in developing countries where the rule of law may be weaker (Maxfield, 1997).

In reality, some central banks are more independent than what is implied by law (such as the Bank of Brazil), while others are less independent than what legal independence would imply (such as in Venezuela). Therefore, legal provisions may not be consistent with de facto independence (Jácome and Vazquez, 2005). For example, although legal indices are important, other aspects of central bank independence such as informal arrangements, tradition and culture of monetary stability are also influential in the setting and carrying out of monetary policy. Therefore, legal independence is not the same as actual independence in many cases for at least two reasons. First, central bank laws are incomplete. Second, even if scope of authority and procedures are described explicitly in the law, actual practice may be differing (Eijffinger et al., 1996).

Moreover, although the degree of legal independence is normally dictated by the central bank laws in a given country, the level of conservativeness can generally be chosen by the central bank. Thus, a lack of legal independence can be compensated for by selecting 
more conservative central bank governors and other directors. A conservative central bank governor will generally place more weight on inflation stabilization (price stability) than society. In other words, a conservative central bank governor leads to a lower inflationary bias, which is optimal for society (Eijffinger and Hoeberichts, 1998).

The implementation of independent central banks constitutes an institutional reform that could add creditability to macroeconomic policy. This measure would at least partially isolate the monetary and exchange rate policy from partisan short-term political battles. However, as the Mexican crisis of 1994-5 clearly indicates, the formal independence of a nation's central bank is not enough to avoid monetary crisis. It is imperative that appropriate monetary policies also be implemented and that it also has political legitimacy. One implication of this is that a central bank should have not only legal independence but also operational independence. For example, as the Venezuelan experience of April 1994 illustrates, when the majority of the central bank board members resigned under political pressure from the executive branch, where there are extreme differences of opinion among the members of the central bank and the executive branch, purely legal independence of the central bank may not be sufficient (Edwards, 1995). However, it seems that the likelihood of independence as well as the degree of independence rises as the differences in political parties and ideologies rise (as was the case in Chile in the 1980s). The rationale for this is that there is an incentive for both political parties to have an independent, neutral central bank that will pursue policies that are roughly in the middle between the desires of the two parties (Alesina, 1988).

In Arnone et al. (2006), the authors examine an updated index of central bank autonomy and apply the index to a set of developed, developing and emerging market countries. The results indicate an increase in central bank autonomy between 1992 and 2003, especially for developing countries. In most cases, this increase is achieved over three stages, from the initial stage in which the foundation for autonomy is laid to the second stage in which operational autonomy develops to the final stage in which further autonomy in terms of policy formulation and leadership is achieved. 


\subsection{Transparency and Corruption}

Transparency of central banks has been defined as the degree of genuine understanding by the public of the monetary policy process and policy decisions (Winkler, 2000). It is the extent to which central banks disclose information that is related to the policymaking process (Eijffinger and Geraats, 2004). There are several general categories of central bank transparency- monetary policy, political, economic, procedural, policy and operational transparency. To express the concept in model form, consider the following equations. First, assume that the central bank maximizes the objective function:

$\mathrm{W}=-1 / 2 \alpha(\pi-\tau)^{2}-1 / 2(1-\alpha)(\mathrm{y}-\mathrm{k})^{2}$

where $\pi$ equals inflation, $\tau$ is the central bank's inflation target, $\alpha$ equals the weight placed on inflation stabilization, $y$ equals the output gap, and $k$ is the output gap target. Further assume:

$\pi=\pi^{\mathrm{e}}+\mathrm{y}+\mathrm{s}$

where $\pi^{e}$ equals expected inflation, $y$ again equals the output gap, and $s$ is a supply shock. Further assume that the aggregate demand equation is expressed by:

$y=-r+d$

where $r$ equals the real interest rate (the central bank's policy instrument) and $d$ is a demand shock. If equations 2 and 3 are then substituted into equation 1, the following may be obtained:

$\mathrm{r}=\alpha\left(\pi^{\mathrm{e}}-\tau\right)-(1-\alpha) \mathrm{k}+\alpha \mathrm{s}_{\mathrm{a}}+\mathrm{d}_{\mathrm{a}}$

where $r$ now reflects both the central bank's preferences and the macroeconomic shocks it foresees. If the central bank releases its forecasts for inflation and output, the private sector can then identify any anticipated macroeconomic shocks and can deduce the central bank's policy preferences using equation 4. Thus, intentions can be inferred from policy actions (Geraats, 2009).

One of the major benefits of increasing the autonomy of central banks is that its actions become more transparent to those observing them. For example, according to Poole et al. 
(2008: p 418), “The more regular and straightforward are Federal Reserve actions and communications, the more the market will focus on fundamentals and the less will it be distracted by incorrect interpretations and speculations." On the other hand, central bank opacity (or lack of transparency) regarding policy decision making causes the policy interest rate to be a noisier signal of the central bank's intentions, thus leading the private sector to be less attuned to these intentions. Additionally, if this is the case, financial markets are likely to put disproportionate weight on public information to coordinate their actions (Geraats, 2009).

Compared with past decades, there is substantially more transparency now in central bank operations relating to monetary policy. To illustrate, in most central banks price stability is by far the most important objective with all other objectives (such as employment, growth, etc.) being secondary to varying degrees (as was the case with the Bank of England Charter of 1997). This represents a vast increase in transparency over previous years because for much of the 20-th Century central banks operated with no clear indication of priorities (Cukierman and Gerlach, 2003).

Although central banks have traditionally been associated with secrecy, as a central bank becomes more independent, it needs to be more accountable for its actions (Fraser, 1994). The main benefits of transparency, according to theoretical models of recent years, is that it enhances the credibility, reputation and flexibility of monetary policy, which should ultimately lead to lower nominal interest rates. However, the actual change in interest rates is dependent upon the degree of actual transparency (Geraats et al., 2006).

In recent years, a number of central banks have moved toward greater transparency regarding their objectives, procedures, rationales, models and data. Additionally, transparency has shown to be greater in countries with more stable and developed political systems and more developed financial markets (Dincer and Eichengreen, 2007). Central banks with inflation targeting regimes in place have experienced the largest expansion in transparency along with countries that suffered high inflation in the 1990s. It also appears that countries with higher monetary policy transparency tend to experience less subsequent inflation (Geraats, 2009). 


\subsection{Measuring Central Bank Independence}

As has been previously stated, there are many nuances of central bank autonomy and independence. Therefore, reliable procedures for measuring the degree of sovereignty must be found in order to gauge the impact of independence or dependence of a respective country's central bank. Cukierman et al. (1993) note the difficulty in quantifying central bank independence, and how legal vs. operational independence can vary, especially in developing countries. In their study, among other things, the authors use the turnover rate of central bank governors as a proxy for actual independence in developing countries, while legal independence is considered an adequate proxy for independence in developed countries. The proxy of central bank governor turnover has since been used in many studies, such as Carstens and Jácome (2005), who found that the average rate in Latin America is 0.4 (meaning that the average central bank governor remains in office around 2.5 years). This high rate of turnover suggests that Latin American central banks still remain vulnerable to political pressures. A central bank is considered more politically independent the longer the governor's term in office (Jácome and Vazquez, 2005).

Several other measures of central bank independence have been proposed in the literature, such as the 1991 Grilli, Masciandaro and Tabellini (GMT) Index, which was one of the first formulated indices for central bank independence (which measures political and economic autonomy), and the original 1992 Cukierman Index, which is based on 16 detailed criteria of central bank independence. However, some more recent authors such as Crowe and Meade (2008) use the Cukierman, Webb and Neyapti (the Modified Cukierman Index) measure described in part above because it is very comprehensive and includes developing as well as developed countries. The index has four components relating to appointment procedures (including a proxy for central bank governor turnover), resolution of conflict, the use of explicit policy targets, and rules limiting lending to the government and is an updated version of the original Cukierman Index.

\section{Hypotheses and Methodology}

We formulate the methodology and hypotheses for this study in this section. 
H1: There is stronger evidence of CBI effectiveness among countries operating under a higher level of operational independence.

H2: There is stronger evidence of CBI effectiveness among countries operating under a higher level of central bank transparency.

H3: There is a beneficial Signaling Effect present with the announcement of Central Bank Independence.

Methodology will include a variety of econometric techniques to test for volatility, correlation and causation with results organized by individual hypothesis. Macroeconomic data from Q1:1960 to Q1:2009 will be taken entirely from the International Monetary Fund (considered a reputable, neutral, global financial institution) in order to maintain consistency of measurements, data collection processes and to avoid biases of individual country central banks or national data collection agencies.

The following macroeconomic variables will be used as dependent variables to measure the impact of central bank independence and outside phenomena on a country's growth and stability and are measured on a quarterly basis. For econometric reasons, the first iteration (first difference) of each variable will be used.

- Inflation (as measured through changes in the Consumer Price Index)

- Unemployment Rates (\%)

- Gross Domestic Product Volume Index

Independent variables will be used to examine the impact of the nuances (political and economic) of central bank independence and related phenomena on the previously mentioned dependent variables. Dummy variables are used frequently to classify data into mutually exclusive categories (Gujarati 2003) and will be used in the following equations to represent, among other things, the effects of country development, foreign exchange rate regimes, the occurrence of financial crises, the degree of international inflation, and the presence of legal CBI. 
Regression analysis is one of the most useful econometric techniques in practice. According to Gujarati (2003): Regression analysis is concerned with the study of the dependence of one variable, the dependent variable, on one or more other variables, the explanatory variables, with a view to estimating and/or predicting the mean or average value of the former in terms of the known or fixed (in repeated sampling) values of the latter (p. 18). The basic regression in this study will take the following form:

$$
\mathrm{y}=\alpha+\beta_{1} \mathrm{CBI} 1+\beta_{2} \mathrm{CBI}_{2}+\beta_{3} \mathrm{CBI}_{3}+\ldots+\varepsilon
$$

The specific regression models given below is an expansion of the above basic model using the dependent variables, which are the objectives of CBI (namely inflation, employment, and GDP growth) and the central bank independence variables as in:

Inflation Rate $=\alpha-\beta_{1}$ Development Dummy $-\beta_{2}$ Modified Cukierman Index $-\beta_{3}$ GMT Index - $\beta_{4}$ Foreign Exchange Rate Regime Dummy $+\beta_{5}$ Financial Crisis Dummy $+\beta_{6}$ International Inflation Dummy $-\beta_{7}$ Legal Central Bank Independence Dummy $+\beta_{8}$ Central Bank Governor Turnover $-\beta_{9}$ IT Dummy $+\beta_{10}$ Cons $-\beta_{11}$ TaxRev $+\varepsilon$

Unemployment $\%=\alpha-\beta_{1}$ Development Dummy $-\beta_{2}$ Modified Cukierman Index $-\beta_{3}$ GMT Index - $\beta_{4}$ Foreign Exchange Rate Regime Dummy $+\beta_{5}$ Financial Crisis Dummy + $\beta_{6}$ International Inflation Dummy $-\beta_{7}$ Legal Central Bank Independence Dummy $+\beta_{8}$ Central Bank Governor Turnover $-\beta_{9}$ IT Dummy $+\beta_{10}$ Cons $-\beta_{11}$ TaxRev $+\varepsilon$

GDP Volume Index $=\alpha+\beta_{1}$ Development Dummy $+\beta_{2}$ Modified Cukierman Index $+\beta_{3}$ GMT Index $+\beta_{4}$ Foreign Exchange Rate Regime Dummy $-\beta_{5}$ Financial Crisis Dummy $\beta_{6}$ International Inflation Dummy $+\beta_{7}$ Legal Central Bank Independence Dummy $-\beta_{8}$ Central Bank Governor Turnover $+\beta_{9}$ IT Dummy $-\beta_{10}$ Cons $+\beta_{11}$ TaxRev $+\varepsilon$

We use Ordinary Least Squares multivariate regression using GARCH to test for correlation and relationships among the variables in question. Regressions will be done across time using time series over the test time period under consideration (quarterly data for almost 50 years with more than 190 observations for most selected cases). The goodness of fit ratio, or $\mathrm{R}^{2}$ will be used to gauge how well each dependent variable is explained by the independent variables. The Durbin-Watson Test will also be used for autocorrelation. A comparison of the $\mathrm{R}^{2}$ and Durbin-Watson test will be used as verification that the regression is not spurious (as mentioned above, if the Durbin-Watson results are quantitatively higher than the $\mathrm{R}^{2}$, this is a sign that the regression is not spurious, or nonsensical). Only results that are at least at the 10 
per cent statistical significance level will be listed throughout the results section and all will be listed with coefficients.

\section{Results}

For the following hypotheses, a representative country for each level will be examined using inflation, GDP Volume and Unemployment rates to ascertain to what degree these variables are influenced by the internal central bank independence characteristics.

H1: There is strong evidence of CBI effectiveness among countries operating under a higher level of operational independence.

The benefit of CBI in terms of stabilizing inflation is mixed. It is noteworthy that in the Medium-High sample, legal CBI has a positive coefficient but MCI (operational independence) has a negative relationship, illustrating the difference that can (and many times do) exist between operational and legal CBI. Also noteworthy are the positive coefficients for international inflation in several subsamples, indicating that the relationship the world inflation levels can have on a particular country's inflation.

Inflation

Table 5.1a: Inflation Results for Operational Independence

\begin{tabular}{|c|c|c|c|}
\hline Level & $\mathbf{R}^{2}$ & DW & $\begin{array}{c}\text { Significant Variables } \\
\text { (Coefficients) }\end{array}$ \\
\hline High (U.S.) & 0.38 & 2.17 & $\begin{array}{c}\text { Cons }(0.49), \text { Deficit } \\
(0.52), \text { Forward }(0.20)\end{array}$ \\
\hline $\begin{array}{l}\text { Medium } \\
\text { High } \\
\text { (Portugal) }\end{array}$ & 0.46 & 1.80 & $\begin{array}{c}\text { MCI (-6.92), LCBI (2.02), } \\
\text { IT }(-2.41), \text { II }(-0.68), \text { DD } \\
(-2.78)\end{array}$ \\
\hline $\begin{array}{l}\text { Medium } \\
\text { (Thailand) }\end{array}$ & 0.11 & 1.29 & II (.96) \\
\hline $\begin{array}{l}\text { Medium } \\
\text { Low } \\
\text { (China) }\end{array}$ & 0.19 & 0.96 & $\mathrm{DD}(22.74), \mathrm{FXD}(4.53)$ \\
\hline $\begin{array}{l}\text { Low } \\
\text { (Japan) }\end{array}$ & 0.36 & 2.17 & $\begin{array}{c}\mathrm{DD}(-1.58), \text { FCD }(.42), \mathrm{II} \\
(1.51), \mathrm{LCBI}(-1.05), \mathrm{MCI} \\
(6.70), \text { TaxRev }(-0.06)\end{array}$ \\
\hline
\end{tabular}

b. GDP Growth 
Table 5.1b; GDP Volume Index Results for Operational Independence

\begin{tabular}{|l|l|l|c|}
\hline \multicolumn{1}{|c|}{ Level } & $\mathbf{R}^{2}$ & DW & $\begin{array}{c}\text { Significant Variables } \\
\text { (Coefficients) }\end{array}$ \\
\hline $\begin{array}{l}\text { High } \\
\text { (U.S.) }\end{array}$ & 0.51 & 2.22 & $\begin{array}{c}\text { Cons (0.35), II (-1.07), } \\
\text { Surplus (0.19), OCBI (- } \\
8.57), \text { Forward (0.26) }\end{array}$ \\
\hline $\begin{array}{l}\text { Medium } \\
\text { High } \\
\text { (Portugal) }\end{array}$ & 0.07 & 2.97 & FCD (-0.77), TaxRev \\
\hline $\begin{array}{l}\text { Medium } \\
\text { (Thailand) }\end{array}$ & 0.28 & 1.72 & $\begin{array}{c}\text { II (1.38), DD (11.10), } \\
\text { Surplus (-0.06) }\end{array}$ \\
\hline $\begin{array}{l}\text { Low } \\
\text { (Japan) }\end{array}$ & 0.01 & 2.60 & None \\
\hline
\end{tabular}

According to the above statistics, there is little evidence to indicate that the degree of operational independence of a central bank is in any way affecting the level of GDP growth.

c) Unemployment

Results for Unemployment in this regard are also unclear. Not only are explained variation very low, the parameter estimates too do not provide strong evidence to support CBI promotes economic growth.

Table 5.1c: Unemployment Results: Operational Independence

\begin{tabular}{|l|l|l|c|}
\hline \multicolumn{1}{|c|}{ Level } & $\mathbf{R}^{\mathbf{2}}$ & DW & $\begin{array}{c}\text { Significant Variables } \\
\text { (Coefficients) }\end{array}$ \\
\hline $\begin{array}{l}\text { High } \\
\text { (U.S.) }\end{array}$ & 0.44 & 2.80 & Cons (-.40), Surplus (-0.42) \\
\hline $\begin{array}{l}\text { Medium } \\
\text { High } \\
\text { (Portugal) }\end{array}$ & 0.13 & 2.03 & Cons (0.10), TaxRev (- \\
\hline $\begin{array}{l}\text { Medium } \\
\text { (Thailand) }\end{array}$ & 0.04 & 2.15 & FCD (0.56) \\
\hline $\begin{array}{l}\text { Medium } \\
\text { Low } \\
\text { (China) }\end{array}$ & & & \\
\hline $\begin{array}{l}\text { Low } \\
\text { (Japan) }\end{array}$ & 0.10 & 2.13 & FXD (-.20) \\
\hline
\end{tabular}


$\mathrm{H} 2$ : There is stronger evidence of CBI effectiveness among countries operating under a higher level of central bank transparency.

a) Inflation

Table 5.2a: Inflation Results and Central Bank Transparency

\begin{tabular}{|l|l|l|c|}
\hline Level & $\mathbf{R}^{2}$ & $\begin{array}{c}\text { D } \\
\mathbf{W}\end{array}$ & $\begin{array}{c}\text { Significant Variables } \\
\text { (Coefficients) }\end{array}$ \\
\hline $\begin{array}{l}\text { High } \\
\text { (New } \\
\text { Zealand) }\end{array}$ & & 1.1 & \\
\hline $\begin{array}{l}\text { Medium } \\
\text { (Brazil) }\end{array}$ & 0.32 & 6 & FXD (0.99), GMT (-0.16) \\
\hline $\begin{array}{l}\text { Low } \\
\text { (Mexico } \\
\text { ) }\end{array}$ & 0.46 & $\begin{array}{c}1.0 \\
6\end{array}$ & GMT (2.36), II (9.11) \\
\hline
\end{tabular}

From the above analysis regarding inflation, it would appear that the most benefit (legally and operationally) from CBI comes at high levels of transparency. At lower levels, there is no clear benefit from CBI.

b) GDP Growth

From the statistics in the table 5.2b, it appears that there is little relationship between CB transparency and GDP growth. This is at all levels of transparency.

Table 5.2b: GDP Volume Index Results and Central Bank Transparency

\begin{tabular}{|l|l|l|c|}
\hline \multicolumn{1}{|c|}{ Level } & $\mathbf{R}^{\mathbf{2}}$ & DW & $\begin{array}{c}\text { Significant Variables } \\
\text { (Coefficients) }\end{array}$ \\
\hline $\begin{array}{l}\text { High } \\
\text { (New } \\
\text { Zealand) }\end{array}$ & 0.07 & 2.45 & FCD (-1.19) \\
\hline $\begin{array}{l}\text { Medium } \\
\text { Brazil) }\end{array}$ & & & Not Available \\
\hline $\begin{array}{l}\text { Low } \\
\text { (Mexico) }\end{array}$ & 0.12 & 3.40 & $\begin{array}{c}\text { DD (22.60), FCD (-2.88), } \\
\text { Surplus (-1.16) }\end{array}$ \\
\hline
\end{tabular}

c) Unemployment 
Table 5.2c: Unemployment Results and Central Bank Transparency

\begin{tabular}{|l|l|l|l|}
\hline Level & $\begin{array}{c}\text { Adj. } \\
\mathbf{R}^{2}\end{array}$ & $\begin{array}{c}\text { D } \\
\text { W }\end{array}$ & $\begin{array}{c}\text { Significant Variables } \\
\text { (Coefficients) }\end{array}$ \\
\hline $\begin{array}{l}\text { High } \\
\text { (New } \\
\text { Zealand) }\end{array}$ & & 2.3 & \\
\hline $\begin{array}{l}\text { Medium } \\
\text { (Brazil) }\end{array}$ & 0.08 & 3 & None \\
\hline $\begin{array}{l}\text { Low } \\
\text { (Mexico) }\end{array}$ & 0.10 & $\begin{array}{c}2.0 \\
6\end{array}$ \\
\hline
\end{tabular}

There appears to be no relationship between central bank transparency and Unemployment levels as could be verified from the results in Table 5.2c.

H3: There is a beneficial signaling effect present with the announcement of Central Bank Independence.

Regression statistics will be examined using event study format for the three target variables as dependent variables: inflation, GDP volume index, and unemployment for the five years immediately prior to each respective country's central bank independence and the five years immediately afterwards, for a total test window of ten years. This is done in order to determine if there is any type of announcement effect (any positive effect just from news being disseminated in the market). One representative country from each region will be examined. Each event study set of results will be compared to the results for the total time period.

Table 5.3a: Inflation Results: Event Study vs. Total Time Period

\begin{tabular}{|l|c|c|}
\hline Region & \multicolumn{1}{|c|}{$\begin{array}{c}\text { Event Study--Significant } \\
\text { Variables (Coefficients) }\end{array}$} & $\begin{array}{c}\text { Total Time Period-Significant } \\
\text { Variables (Coefficients) }\end{array}$ \\
\hline $\begin{array}{l}\text { Asia } \\
\text { (Japan) }\end{array}$ & None & $\begin{array}{c}\text { DD(-1.58), FCD (.42), II (1.51), LCBI (- } \\
1.05), \text { MCI (6.70), TaxRev (-0.06) }\end{array}$ \\
\hline $\begin{array}{l}\text { Latin } \\
\text { America } \\
\text { (Mexico }\end{array}$ & $\begin{array}{c}\text { LCBI (18.12), GMT (-2.65), } \\
\text { CBGov (51.62), II (2.66) }\end{array}$ & CBGov (-0.01), DD (-3.63), II (0.06) \\
\hline $\begin{array}{l}\text { Develop } \\
\text { ed West } \\
\text { (U.S.) }\end{array}$ & None & $\begin{array}{c}\text { Cons (0.49), Deficit (0.52), Forward } \\
(0.20)\end{array}$ \\
\hline
\end{tabular}


It is apparent from the statistics in Table 5.3a that there is very little beneficial signaling effect regarding CBI on inflation. For Mexico, where the Legal CBI variable appears significant, it is actually positively correlated with inflation instead of the theory-suggested negative sign. In the other regions, LCBI is not significant at all. However, operational CBI is negatively related to inflation in Mexico, perhaps indicating a slight increase in de facto power on the part of the respective central bank to curb inflation. Next, GDP volume is examined.

Table 5.3b: GDP Volume Index Results: Event Study vs. Total Time Period

\begin{tabular}{|l|c|c|}
\hline \multicolumn{1}{|c|}{ Region } & $\begin{array}{c}\text { Event Study--Significant } \\
\text { Variables (Coefficients) }\end{array}$ & $\begin{array}{c}\text { Total Time Period_Significant } \\
\text { Variables (Coefficients) }\end{array}$ \\
\hline $\begin{array}{l}\text { Asia } \\
\text { (Japan) }\end{array}$ & MCI (10.38) & None \\
\hline $\begin{array}{l}\text { Latin } \begin{array}{l}\text { America } \\
\text { (Mexico) }\end{array} \\
\begin{array}{l}\text { Develope } \\
\text { d West } \\
\text { (U.S.) }\end{array}\end{array} \quad$ None & DD (22.60), FCD (-2.88), Surplus (-1.16) \\
\hline
\end{tabular}

In Asia, there is a positive relationship between operational independence as expressed through MCI and an increase in the GDP volume index. Therefore, there is some evidence to support the possibility of an announcement type effect for this region.

Table 5.3c: Unemployment Results, Event Study vs. Total Time Period

\begin{tabular}{|l|c|c|}
\hline \multicolumn{1}{|c|}{ Region } & $\begin{array}{c}\text { Event Study--Significant } \\
\text { Variables (Coefficients) }\end{array}$ & $\begin{array}{c}\text { Total Time Period-Significant } \\
\text { Variables (Coefficients) }\end{array}$ \\
\hline Asia (Japan) & LCBI (0.61) & DD (-0.95), GMT (0.13), LCBI (0.40), \\
\hline $\begin{array}{l}\text { Latin } \\
\begin{array}{l}\text { America } \\
\text { (Mexico) }\end{array}\end{array}$ & FCD (0.1.77) \\
\hline $\begin{array}{l}\text { Developed } \\
\text { West (U.S.) }\end{array}$ & None & Surplus (0.12) \\
\hline
\end{tabular}

Next, Unemployment is examined. As can be seen, there seems to be no announcement effect for unemployment. However, it is of note that the financial crisis variable is positively correlated with unemployment in Latin America during this time period. 
As can be seen, there seems to be no announcement effect for unemployment. However, it is of note that the financial crisis variable is positively correlated with unemployment in Latin America during this time period.

\section{Conclusion}

The following Table 6 is a summary of the findings from this research using an extensive data set on several countries.

\section{Table 6: Summary of Findings on Central Bank Independence}

1. On inflation, there is some evidence that a higher operationally independent central bank is associated with lowering inflation. For the other two variables, there is little evidence that independence promotes growth or employment.

2. There is some correlation between lower levels of inflation and high central bank transparency. However, there is no evidence growth or employment is promoted.

3. There is some evidence for a CBI signaling effect that spurs economic growth through an increase in operational CBI, but little support for growth or for employment.

The idea of central bank independence has been at the forefront of financial market liberalization since the late 1980s and is still considered quite relevant (de Haan et al., 2008). Many countries around the world, both developed and developing, have granted autonomy to their central banks in order to achieve monetary and fiscal objectives. There are several general motives put forth in the literature as to what macroeconomic and political events drove countries to grant this authority. However, the results in the early literature on the subject, with some exceptions, seemed to come to a common conclusion that an increase in central bank independence would lead to a lower inflation rates. However, much of the early work was done in the 1990s before many of the developing and developed country central banks had achieved independence. 
This study is an attempt to update and expand upon empirical studies using a current lengthier and richer database, available more appropriate methodology and an increased perspective of the potential gains from central bank independence. One of the main objectives of this study has been to examine the nuances of operational vs. legal central bank independence. Given the fact that now sufficient post-independence data over 10-15 years or more are available, it is now possible to quantify the potential benefits of central bank independence by examining countries that achieved CBI in the 1990s. The verdict from this study is that there is still more work needed to verify if central bank independence is correlated with not just inflation but also growth and employment.

Author information: Dr Carroll Howard Griffin is a staff member in Eckelkamp College of Global Business and Professional Studies, Fontbonne University, 6800 Wydown Blvd., St. Louis MO 63105, United States: E-mail: chgriffin@ @otmail.com.

\section{References}

Acemoglu, D., Johnson, S., Querubin, P., \& Robinson, J. (2008). When does policy reform work? The case of central bank independence. NBER Working Paper 14033.

Alesina, A. (1988). Macroeconomics and politics. NBER Macroeconomics Annual, 1988. (Cambridge, MA: MIT Press).

Arnone, M., Laurens, B., \& Segalotto, J. (2006). Measures of central bank autonomy: Empirical evidence for OECDs, developing, and emerging market economies. IMF Working Paper, 06/228.

Boylan, D. (2001). Defusing Democracy: Central Bank Autonomy and the Transition from Authoritarian Rule.

Carlstrom, C., \& Fuerst, T. (2006, September). Central bank independence: The key to price stability? Federal Reserve Bank of Cleveland.

Carstens, A., \& Jácome, L. (2005). Latin American central bank reform: Progress and challenges. IMF Working Paper. WP/05/114.

Crowe, C., \& Meade, E. (2008). Central bank independence and transparency: Evolution and effectiveness. IMF Working Paper. WP/08/119. 
Cukierman, A., (1994, November). Central bank independence and monetary control. The Economic Journal, 104: 1437-1448.

Cukierman, A., and Gerlach, S., (2003). The inflation bias revisited: Theory and some international evidence. The Manchester School, 71(5): 541- 565.

Cukierman, A., Kalaitzidakis, P., Summers, L., and Webb, S., (1993). Central bank independence, growth, investment, and real rates. Carnegie-Rochester Conference Series on Public Policy, 39: 95-140.

Cukierman, A., Webb, S., and Neyapti, B., (1992). Measuring the autonomy of central banks and its effects on policy outcomes. The World Bank Economic Review, 6: 353398.

de Haan, J., Masciandaro, D., and Quintyn, M. (2008)., Does central bank independence still matter? European Journal of Political Economy 24: 717-721.

Diana, G., and Sidiropoulos, M., (2004). Central bank independence, speed of disinflation and the sacrifice ratio. Open Economic Review 15: 385-402.

Dincer, N., and Eichengreen, B., (2007, March). Central bank transparency: where, why and with what effects? National Bureau of Economic Research. Working Paper No. 13003.

Edwards, S., (1995). Crisis and Reform in Latin America: From Despair to Hope. The World Bank. Oxford University Press.

Eijffinger, S., and Hoeberichts, M., (1998). The trade-off between central bank independence and conservativeness. Oxford Economic Papers, 50: 397-411.

Eijffinger, S., \& Geraats, P. (2004). How transparent are central banks? Unpublished manuscript.

Eijffinger, S., Van Rooij, M., \& Schaling, E. (1996). Central bank independence: A panel data approach. Public Choice, 89(1-2): 163-182.

Forder, J. (2005). Why is central bank independence so widely approved? Journal of Economic Issues, 39(4): 843-858.

Fraser, B. W., (1994, December). Central bank independence: What does it mean? Reserve Bank of Australia Bulletin, 1-8.

Geraats, P., (2009, February). Trends in monetary policy transparency. CESifo. Working Paper No. 2584.

Geraats, P., Eijffinger, S., and van der Cruijsen, C.. (2006, February). Does central bank transparency reduce interest rates? Centre for Economic Policy Research. Discussion Paper No. 5526. 
Grilli, V., Masciandaro, D., and Tabellini, G., (1991). Political and monetary institutions and public financial policies in the industrial countries. Economic Policy, 13: $341-392$.

Gruben, W., and Welch, J., (1993). Interpreting central bank independence in Mexico. Federal Reserve Bank of Dallas.

Gujarati, D. (2003). Basic Econometrics. (Fourth edition). McGraw-Hill Publishers.

Gutiérrez, E., (2003). Inflation performance and constitutional central bank independence: Evidence from Latin America and the Caribbean. IMF Working Paper. $\mathrm{WP} / 03 / 53$.

International Monetary Fund. www.imf.org.

Jácome, L. and Vázquez, F., (2005). Any link between legal central bank independence and inflation? Evidence from Latin America and the Caribbean. IMF Working Paper. $\mathrm{WP} / 05 / 75$.

Maxfield, S., (1997). Gatekeepers of Growth: The International Political Economy of Central Banking in Developing Countries. Princeton, NJ: Princeton University Press.

Poole, W., (2008, July/August). The importance of being predictable. Review. Federal Reserve Bank of St. Louis, 415-419.

Sirivedhin, T., and Hataiseree, R., (2000, January). Central bank independence: A Thai perspective. SEANZA Advisors' Meeting.

Winkler, B., (2000). Which kind of transparency? On the need for clarity in monetary policymaking. ECB Working Paper, 26. 